Historic, Archive Document

Do not assume content reflects current scientific knowledge, policies, or practices. 



\begin{abstract}
Edminster, Carleton B., and Frank G. Hawksworth.

1976. User's guide to SWYLD2: Yield tables for even-aged and two-storied stands of southwestern ponderosa pine, including effects of dwarf mistletoe. USDA For. Serv. Gen. Tech. Rep. RM-23, 8 p. Rocky Mt. For. and Range Exp. Stn., Fort Collins, Colo.

Describes procedures for application of computer program SWYLD2 (Myers and others 1976) for yield simulation of even-aged and two-storied stands of southwestern ponderosa pine, including the effects of dwarf mistletoe. SWYLD2 supersedes SWYLD program, published in USDA For. Serv. Res. Pap. RM-87, 1972.
\end{abstract}

Keywords: Pinus ponderosa, Arceuthobium vaginatum, stand yield tables, simulation. 


\title{
User's Guide to SWYLD2: Yield Tables for Even-Aged and Two-Storied Stands of Southwestern Ponderosa Pine, Including Effects of Dwarf Mistletoe
}

\author{
Carleton B. Edminster and Frank G. Hawksworth
}

\section{Introduction}

Computer program SWYLD2 (Myers and others 1976) has been developed to compute yield tables for even-aged and two-storied stands of southwestern ponderosa pine (Pinus ponderosa Laws.), including effects of dwarf mistletoe (Arceuthobium vaginatum subsp. cryptopodum (Engelm.) Hawksw. \& Wiens). Program SWYLD2 has been written to supersede program SWYLD (Myers and others 1972), and has the capability of handling a wider range of stand situations and management decisions. This report describes certain procedures for application of SWYLD2 in studying management alternatives for existing and hypothetical stands.

Stands to be analyzed using SWYLD2 should be even-aged or two-storied. In even-aged stands, diameters of most trees will not differ greatly from the average diameter of the stand. The diameter distribution will generally follow a unimodal distribution (fig. 1). Although the range of tree diameters in an even-aged stand will increase with stand age and time since treatment, stands with a range in diameters greater than 12 inches may not be even-aged (Hawksworth and Myers 1973) and may have to be treated as twostoried. Two-storied stands will appear to be

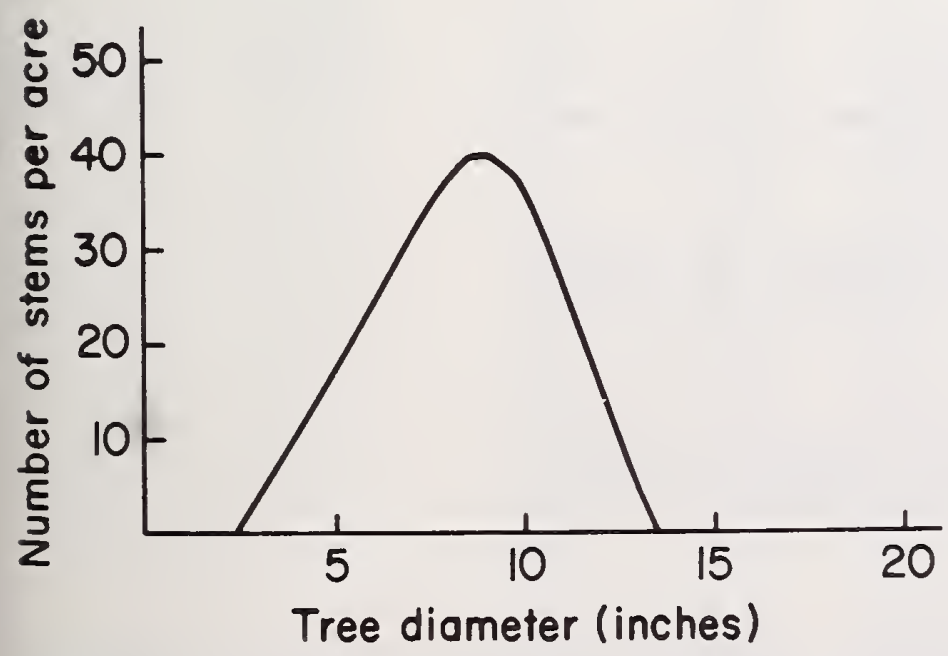

Figure 1.-Idealized diameter distribution for an even-aged stand. two-aged, and ages of trees in the smaller diameter classes will be much less than ages of trees in the larger diameter classes. The diameter distribution of trees in a two-storied stand will generally follow a bimodal distribution (fig. 2). Two-storied stands may occur naturally or may result from a seed cut of a shelterwood followed by regeneration under the residual overstory.

The stand must be relatively uniform in species composition, site quality, stand structure, tree density, and past treatment. SWYLD2 may be used to predict yields in stands with or without dwarf mistletoe. In infested stands, dwarf mistletoe should be distributed fairly generally over the area. If part of the area is free of dwarf mistletoe, it should be analyzed as a separate stand. Stands of any size may be analyzed, since the yield tables give values for an average acre. Uniformity of site quality and stand characteristics must be such that site index and other area averages accurately describe the unit of forest analyzed. Stand area may range from a very few acres in rough terrain to a hundred or more acres where meaningful averages may be computed (Myers and others 1976).

Occasional trees of different species may be present in the stand being analyzed. These trees will be included in the stand data as though they

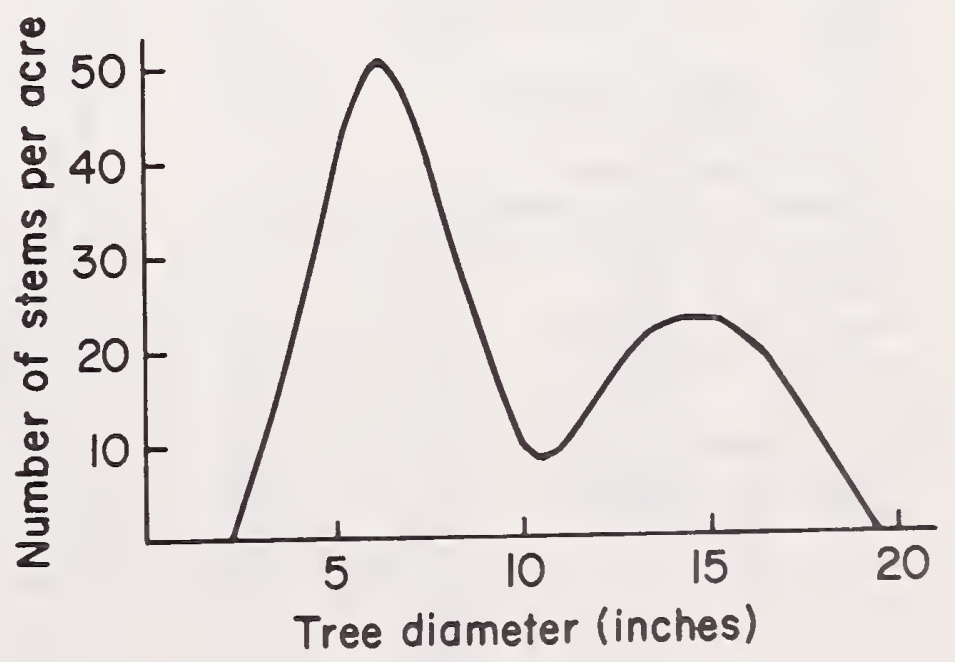

Figure 2.-Idealized diameter distribution for a twostoried stand. 
are members of the main stand; they should be included in computations of average diameter and number of stems per acre. The amount of species variation that may exist before accuracy is significantly reduced will depend on the relative growth rate of the species (Hawksworth and Myers 1973). Generally no more than 10 percent of the trees should be of different species.

\section{Dwarf Mistletoe}

In SWYLD2, dwarf mistletoe infestation is measured by the 6-class rating system (Hawksworth 1961). A rating is obtained for each live tree, as shown in figure 3. In even-aged stands, the individual ratings are then averaged to obtain the value for the entire stand. In two-storied stands, separate averages are computed for the overstory and understory.

SWYLD2 allows information on the dwarf mistletoe infestation to be reported in one of three ways for an even-aged stand, or for each story in a two-storied stand: (1) average dwarf mistletoe rating (DMR), (2) percentage of infected live trees (PINF), or (3) age at time of initial infestation (START). Only one of these three alternatives should be used to report information on the infestation. If possible, DMR or PINF should be used. Walters (1975) describes sampling methods for determining the percentage of infected trees in southwestern ponderosa pine stands. START is not merely the age when the earliest infection occurred, but the mean age when infection began at various points throughout the stand. START may be difficult to obtain because it requires direct aging of infections, but may be useful in studying hypothetical stands for the development of management guidelines.

\section{Control of Stand Density}

Growing stock levels are used to specify the intensity of all partial cuts. Growing stock levels are designated by the square feet of basal area per acre desired when average stand diameter (d.b.h.) is 10 inches or more (Myers 1971). Basal area in a stand or story of smaller average d.b.h. is less than the designated level, as shown in figure 4 and table 1 . In an even-aged stand, for example, if a growing stock level of 80 is desired and the stand is expected to have an average d.b.h. after thinning of 5.0 inches, the basal area to be retained is 46.8 square feet per acre. If a growing stock level of 100 is desired, $(100 / 80) \times 46.8$, or 58.5 square feet per acre will be left (Hawksworth and Myers 1973). Table 1 can also be used to estimate the appropriate growing stock level if it is desired to leave a certain residual basal area for a given average d.b.h.

Table 2 relates average d.b.h. after thinning to average d.b.h. before thinning for various intensities of thinning. Table 3 relates the average spacing between residual trees to average d.b.h. after thinning for various growing stock levels. Table 4 relates the number of residual stems per acre to average d.b.h. after thinning.

INSTRUCTIONS

EXAMPLE

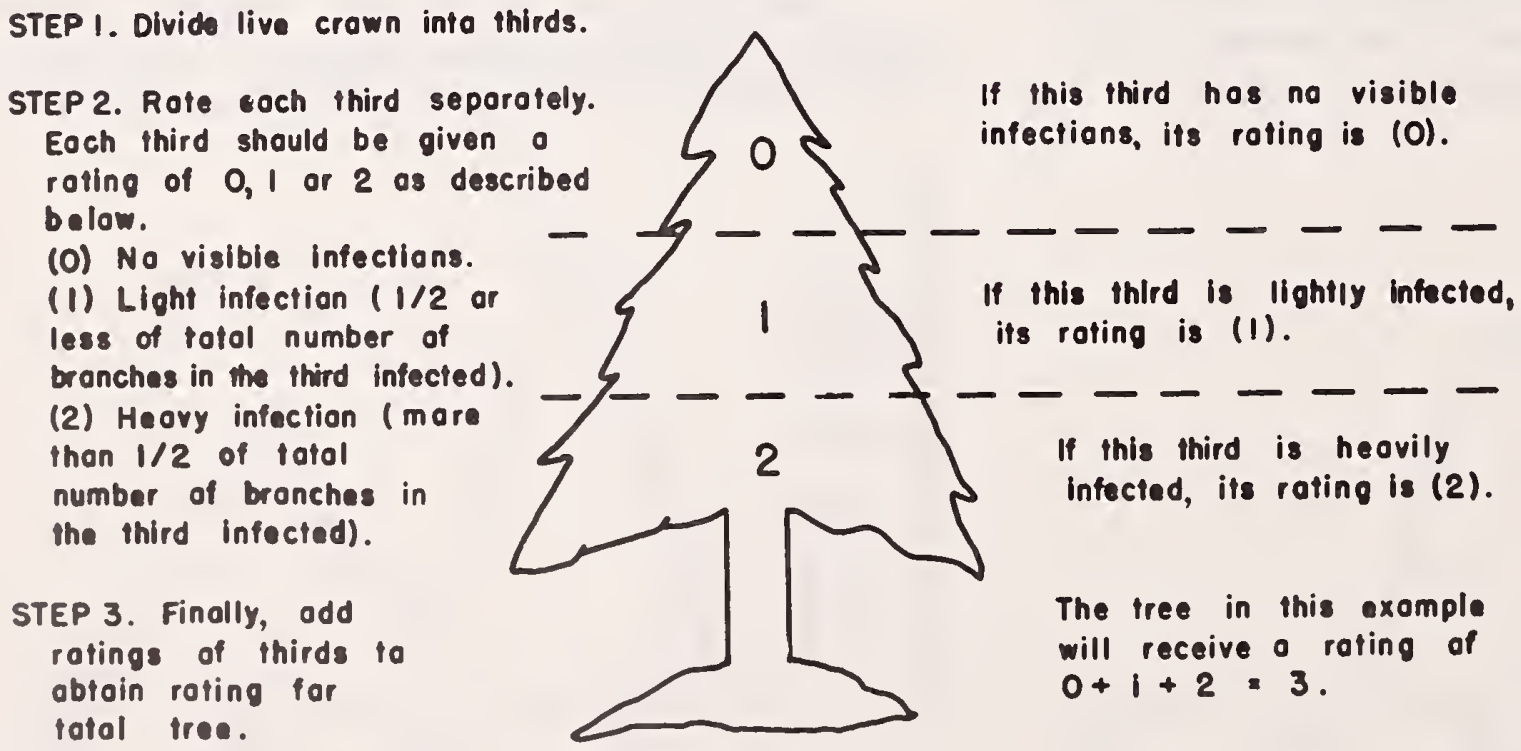

Figure 3.-Instructions for and example of the use of the 6-class mistletoe rating system (from Hawksworth 1971). 


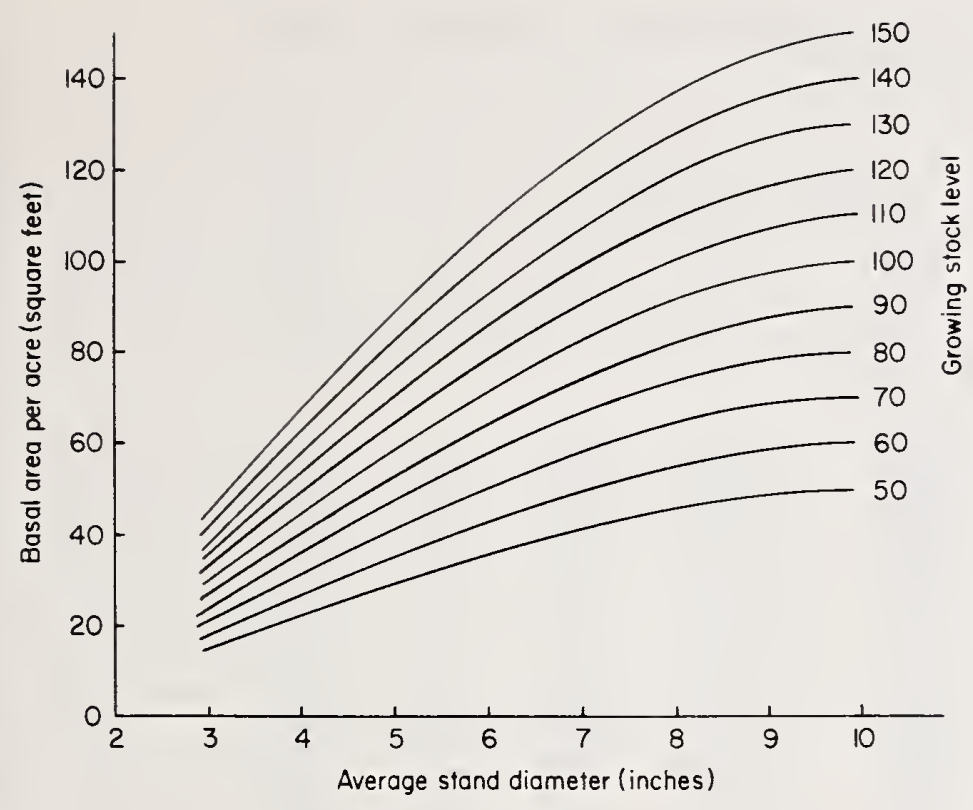

Figure 4.-Basal area after thinning in relation to average stand diameter for standard levels of growing stock (from Myers 1971).

SWYLD2 executes thinnings and regeneration cuts separately for each story in two-storied stands. Thus it is possible for the user to specify simultaneous cuttings in both the overstory and understory, or a cutting may be specified in only one story. Growing stock level specified for a cutting applies only to the basal area and average diameter of the story involved, and not to the combined basal area of both stories. A separate yield table is printed for each story in two-storied stands.

\section{User-Supplied Information}

Values of 38 variables that describe stand conditions or control program execution are read from data cards supplied by the program user. Names and definitions of these variables are given in the tabulation headed Contents of the Data Deck. Input formats and a sample data form are shown in figure 5. With the exception of card type 3, all data must be right-justified in the appropriate fields. Decimal points need not be punched, and are shown in figure 5 only for reference by the user.

The data deck for SWYLD2 consists of six different card types. Card types 1 and 2 appear at the beginning of the data deck. Only one set of these cards is read during a single computer run. Sets of card types $3,4,5$, and 6 must appear for each different stand condition or set of management controls to be studied.

Table 1. Basal areas after partial cutting in relation to average diameter and growing stock level

\begin{tabular}{|c|c|c|c|c|c|c|c|}
\hline \multirow{2}{*}{$\begin{array}{l}\text { Average } \\
\text { d.b.h. } \\
\text { after } \\
\text { cutting } \\
\text { (Inches) }\end{array}$} & \multicolumn{7}{|c|}{ Growing stock level } \\
\hline & 40 & 60 & 80 & 100 & 120 & 140 & 160 \\
\hline & \multicolumn{7}{|c|}{ - - - Square feet - - - } \\
\hline $\begin{array}{l}1.0 \\
1.5 \\
2.0 \\
2.5 \\
3.0\end{array}$ & $\begin{array}{r}3.0 \\
4.6 \\
6.0 \\
9.0 \\
11.8\end{array}$ & $\begin{array}{r}4.5 \\
6.8 \\
9.1 \\
13.4 \\
17.8\end{array}$ & $\begin{array}{r}6.0 \\
9.1 \\
12.1 \\
17.9 \\
23.7\end{array}$ & $\begin{array}{r}7.5 \\
11.4 \\
15.1 \\
22.4 \\
29.6\end{array}$ & $\begin{array}{r}9.0 \\
13.6 \\
18.2 \\
26.8 \\
35.6\end{array}$ & $\begin{array}{l}10.5 \\
15.9 \\
21.2 \\
31.3 \\
41.5\end{array}$ & $\begin{array}{l}12.0 \\
18.2 \\
24.2 \\
35.8 \\
47.4\end{array}$ \\
\hline $\begin{array}{l}3.5 \\
4.0 \\
4.5 \\
5.0 \\
5.5\end{array}$ & $\begin{array}{l}14.8 \\
17.6 \\
20.5 \\
23.4 \\
25.9\end{array}$ & $\begin{array}{l}22.1 \\
26.4 \\
30.8 \\
35.1 \\
38.8\end{array}$ & $\begin{array}{l}29.5 \\
35.2 \\
41.0 \\
46.8 \\
51.8\end{array}$ & $\begin{array}{l}36.9 \\
44.0 \\
51.2 \\
58.5 \\
64.8\end{array}$ & $\begin{array}{l}44.2 \\
52.8 \\
61.5 \\
70.2 \\
77.7\end{array}$ & $\begin{array}{l}51.6 \\
61.6 \\
71.8 \\
81.9 \\
90.6\end{array}$ & $\begin{array}{r}59.0 \\
70.4 \\
82.0 \\
93.6 \\
103.6\end{array}$ \\
\hline $\begin{array}{l}6.0 \\
6.5 \\
7.0 \\
7.5 \\
8.0\end{array}$ & $\begin{array}{l}28.3 \\
30.6 \\
32.7 \\
34.6 \\
36.2\end{array}$ & $\begin{array}{l}42.4 \\
45.9 \\
49.0 \\
51.9 \\
54.4\end{array}$ & $\begin{array}{l}56.6 \\
61.2 \\
65.4 \\
69.2 \\
72.5\end{array}$ & $\begin{array}{l}70.8 \\
76.5 \\
81.8 \\
86.5 \\
90.6\end{array}$ & $\begin{array}{r}84.9 \\
91.8 \\
98.1 \\
103.8 \\
108.8\end{array}$ & $\begin{array}{r}99.0 \\
107.1 \\
114.4 \\
121.1 \\
126.9\end{array}$ & $\begin{array}{l}113.2 \\
122.4 \\
130.8 \\
138.4 \\
145.0\end{array}$ \\
\hline $\begin{array}{c}8.5 \\
9.0 \\
9.5 \\
10.0+\end{array}$ & $\begin{array}{l}37.6 \\
38.8 \\
39.6 \\
40.0\end{array}$ & $\begin{array}{l}56.5 \\
58.1 \\
59.3 \\
60.0\end{array}$ & $\begin{array}{l}75.3 \\
77.5 \\
79.1 \\
80.0\end{array}$ & $\begin{array}{r}94.1 \\
96.9 \\
98.9 \\
100.0\end{array}$ & $\begin{array}{l}113.0 \\
116.2 \\
118.6 \\
120.0\end{array}$ & $\begin{array}{l}131.8 \\
135.6 \\
138.4 \\
140.0\end{array}$ & $\begin{array}{l}150.6 \\
155.0 \\
158.2 \\
160.0\end{array}$ \\
\hline
\end{tabular}


Table 2. Average diameters after partial cutting from below to various levels 1

\begin{tabular}{|c|c|c|c|c|c|c|c|c|c|}
\hline \multirow{2}{*}{$\begin{array}{c}\text { Average } \\
\text { d.b.h. } \\
\text { before } \\
\text { cutting } \\
\text { (Inches) }\end{array}$} & \multicolumn{9}{|c|}{ Percentage of trees retained } \\
\hline & 10 & 20 & 30 & 40 & 50 & 60 & 70 & 80 & 90 \\
\hline $\begin{array}{l}1.0 \\
2.0 \\
3.0 \\
4.0 \\
5.0\end{array}$ & $\begin{array}{l}1.9 \\
3.3 \\
4.7 \\
6.0 \\
7.2\end{array}$ & $\begin{array}{l}1.6 \\
2.9 \\
4.2 \\
5.4 \\
6.6\end{array}$ & $\begin{array}{l}1.4 \\
2.7 \\
3.9 \\
5.1 \\
6.2\end{array}$ & $\begin{array}{c}-- \\
1.4 \\
2.6 \\
3.8 \\
4.9 \\
6.0\end{array}$ & $\begin{array}{l}\text { nches } \\
1.3 \\
2.5 \\
3.8 \\
4.8 \\
5.8\end{array}$ & $\begin{array}{c}--- \\
1.2 \\
2.4 \\
3.7 \\
4.7 \\
5.7\end{array}$ & $\begin{array}{l}1.2 \\
2.3 \\
3.5 \\
4.5 \\
5.6\end{array}$ & $\begin{array}{l}1.2 \\
2.3 \\
3.3 \\
4.4 \\
5.4\end{array}$ & $\begin{array}{l}1.1 \\
2.2 \\
3.1 \\
4.1 \\
5.2\end{array}$ \\
\hline $\begin{array}{r}6.0 \\
7.0 \\
8.0 \\
9.0 \\
10.0\end{array}$ & $\begin{array}{r}8.4 \\
9.6 \\
10.8 \\
11.9 \\
13.0\end{array}$ & $\begin{array}{r}7.7 \\
8.9 \\
10.0 \\
11.1 \\
12.1\end{array}$ & $\begin{array}{r}7.3 \\
8.4 \\
9.5 \\
10.6 \\
11.7\end{array}$ & $\begin{array}{r}7.1 \\
8.2 \\
9.2 \\
10.3 \\
11.3\end{array}$ & $\begin{array}{r}6.9 \\
7.9 \\
8.9 \\
9.9 \\
10.9\end{array}$ & $\begin{array}{r}6.7 \\
7.7 \\
8.8 \\
9.8 \\
10.8\end{array}$ & $\begin{array}{r}6.6 \\
7.6 \\
8.6 \\
9.6 \\
10.7\end{array}$ & $\begin{array}{r}6.4 \\
7.4 \\
8.4 \\
9.5 \\
10.5\end{array}$ & $\begin{array}{r}6.2 \\
7.2 \\
8.2 \\
9.2 \\
10.3\end{array}$ \\
\hline $\begin{array}{l}12.0 \\
14.0 \\
16.0 \\
18.0 \\
20.0\end{array}$ & $\begin{array}{l}15.2 \\
17.3 \\
19.3 \\
21.4 \\
23.3\end{array}$ & $\begin{array}{l}14.2 \\
16.3 \\
18.4 \\
20.4 \\
22.4\end{array}$ & $\begin{array}{l}13.7 \\
15.8 \\
17.8 \\
19.8 \\
21.8\end{array}$ & $\begin{array}{l}13.4 \\
15.4 \\
17.5 \\
19.5 \\
21.4\end{array}$ & $\begin{array}{l}13.0 \\
15.0 \\
17.1 \\
19.1 \\
21.1\end{array}$ & $\begin{array}{l}12.8 \\
14.9 \\
16.9 \\
19.0 \\
21.0\end{array}$ & $\begin{array}{l}12.7 \\
14.7 \\
16.8 \\
18.8 \\
20.9\end{array}$ & $\begin{array}{l}12.5 \\
14.6 \\
16.6 \\
18.6 \\
20.7\end{array}$ & $\begin{array}{l}12.3 \\
14.3 \\
16.4 \\
18.4 \\
20.5\end{array}$ \\
\hline $\begin{array}{l}25.0 \\
30.0\end{array}$ & $\begin{array}{l}28.2 \\
32.9\end{array}$ & $\begin{array}{l}27.2 \\
32.0\end{array}$ & $\begin{array}{l}26.7 \\
31.5\end{array}$ & $\begin{array}{l}26.3 \\
31.2\end{array}$ & $\begin{array}{l}26.2 \\
31.2\end{array}$ & $\begin{array}{l}26.1 \\
31.2\end{array}$ & $\begin{array}{l}26.0 \\
31.1\end{array}$ & $\begin{array}{l}25.8 \\
30.9\end{array}$ & $\begin{array}{l}25.6 \\
30.7\end{array}$ \\
\hline
\end{tabular}

1These values are for healthy stands. In dwarf mistletoe-infested stands, the increase in average d.b.h. will be half the change indicated in the table.

Table 3. Average distance between residual trees in relation to average diameter and growing stock level

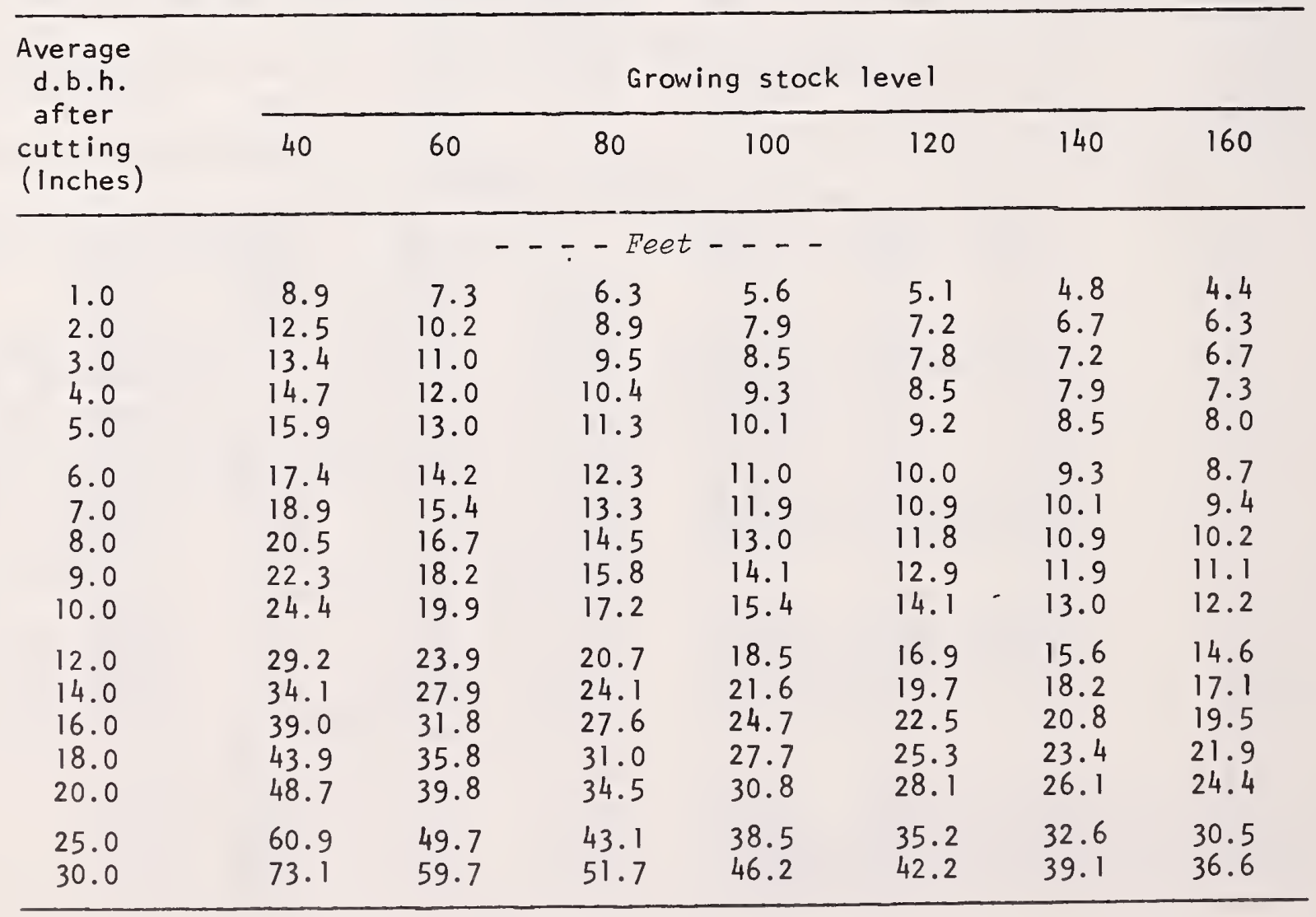


Table 4. Number of residual stems per acre in relation to average diameter and growing stock level

\begin{tabular}{|c|c|c|c|c|c|c|c|}
\hline \multirow{2}{*}{$\begin{array}{l}\text { Average } \\
\text { d.b.h. } \\
\text { after } \\
\text { cutting } \\
\text { (Inches) }\end{array}$} & \multicolumn{7}{|c|}{ Growing stock level } \\
\hline & 40 & 60 & 80 & 100 & 120 & 140 & 160 \\
\hline & & & -- & tems $p$ & $e-$ & & \\
\hline $\begin{array}{l}1.0 \\
2.0 \\
3.0 \\
4.0 \\
5.0\end{array}$ & $\begin{array}{l}553 \\
277 \\
241 \\
202 \\
172\end{array}$ & $\begin{array}{l}830 \\
415 \\
361 \\
303 \\
258\end{array}$ & $\begin{array}{r}1,107 \\
553 \\
482 \\
404 \\
343\end{array}$ & $\begin{array}{r}1,383 \\
692 \\
602 \\
505 \\
429\end{array}$ & $\begin{array}{r}1,660 \\
830 \\
723 \\
606 \\
515\end{array}$ & $\begin{array}{r}1,937 \\
968 \\
843 \\
707 \\
601\end{array}$ & $\begin{array}{r}2,213 \\
1,107 \\
964 \\
808 \\
687\end{array}$ \\
\hline $\begin{array}{r}6.0 \\
7.0 \\
8.0 \\
9.0 \\
10.0\end{array}$ & $\begin{array}{r}144 \\
122 \\
104 \\
88 \\
73\end{array}$ & $\begin{array}{l}216 \\
184 \\
156 \\
132 \\
110\end{array}$ & $\begin{array}{l}288 \\
245 \\
208 \\
175 \\
147\end{array}$ & $\begin{array}{l}361 \\
306 \\
260 \\
219 \\
183\end{array}$ & $\begin{array}{l}433 \\
367 \\
312 \\
263 \\
220\end{array}$ & $\begin{array}{l}505 \\
428 \\
364 \\
307 \\
257\end{array}$ & $\begin{array}{l}577 \\
489 \\
415 \\
351 \\
293\end{array}$ \\
\hline $\begin{array}{l}12.0 \\
14.0 \\
16.0 \\
18.0 \\
20.0\end{array}$ & $\begin{array}{l}51 \\
37 \\
29 \\
23 \\
18\end{array}$ & $\begin{array}{l}76 \\
56 \\
43 \\
34 \\
28\end{array}$ & $\begin{array}{r}102 \\
75 \\
57 \\
45 \\
37\end{array}$ & $\begin{array}{r}127 \\
94 \\
72 \\
57 \\
46\end{array}$ & $\begin{array}{r}153 \\
112 \\
86 \\
68 \\
55\end{array}$ & $\begin{array}{l}178 \\
131 \\
100 \\
79 \\
64\end{array}$ & $\begin{array}{r}204 \\
150 \\
115 \\
91 \\
73\end{array}$ \\
\hline $\begin{array}{l}25.0 \\
30.0\end{array}$ & $\begin{array}{r}12 \\
8\end{array}$ & $\begin{array}{l}18 \\
12\end{array}$ & $\begin{array}{l}23 \\
16\end{array}$ & $\begin{array}{l}29 \\
20\end{array}$ & $\begin{array}{l}35 \\
24\end{array}$ & $\begin{array}{l}41 \\
29\end{array}$ & $\begin{array}{l}47 \\
33\end{array}$ \\
\hline
\end{tabular}

Values of variables associated with the understory of two-storied stands on card types 4 and 5 should be left blank or set to zero if the stand being studied is even-aged. Only the stand and overstory values are used for even-aged stands.

As mentioned earlier, only one of the three alternative ways of reporting the level of a dwarf mistletoe infestation should be used. The values for the remaining two variables should be set to zero or left blank. Different alternatives may be used for each story in a two-storied stand. For example, average DMR might be used for an infested overstory and PINF for the understory.

The alternative of no management can be simulated by not performing any thinnings during the life of the stand. To suppress thinnings, the values of DELAY and JCYCL on card type 4 should be set to the difference between the removal age for clearcutting, REGN(1) on card type 6 , and initial stand or story age, AGEO on card type 5 .

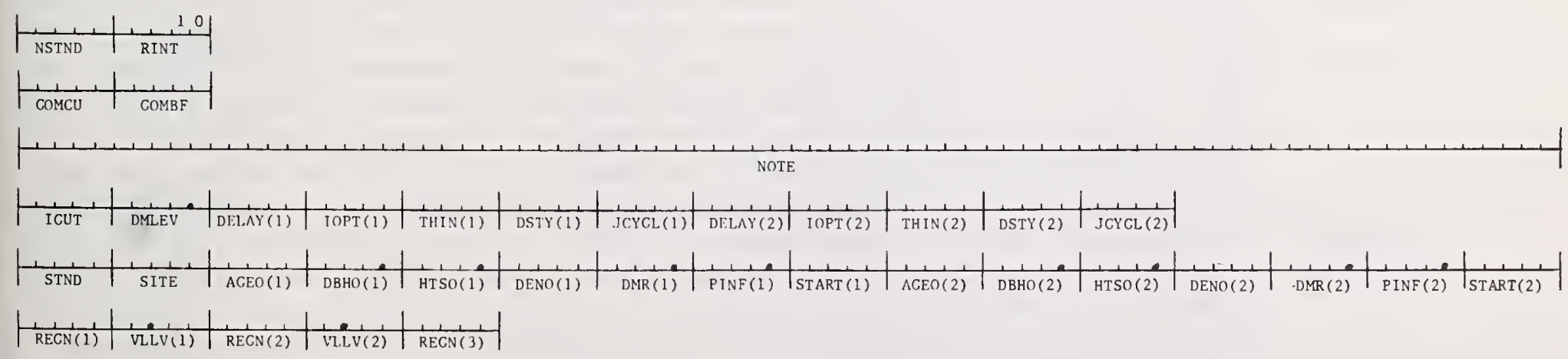

Figure 5.-Sample input data form for program SWYLD2 (decimal points are shown for user reference, and need not be punched). 


\section{Contents of the Data Deck}

Card type 1-header:

NSTND - Number of sets of stand records to be processed in a single computer run. This is the number of sets of card types $3,4,5,6$ to follow in the data deck.

RINT - Number of years in a projection of growth or change. The value of RINT is 10.0 for the equations in SWYLD2.

\section{Card type 2-commercial limits:}

COMCU - Minimum cut in merchantable cubic feet per acre to be included in total yields. The value of COMCU is also used to determine if a thinning meets commercial limits, if any are imposed. See ICUT, card type 4. COMCU must have a value of at least 1.0.

COMBF - Minimum cut in board feet per acre to be included in total yields. The value of COMBF is also used to determine if a thinning meets commercial limits, if any are imposed. See ICUT, card type 4. COMBF must have a value of at least 1.0.

\section{Card type 3-stand identification:}

NOTE - Stand identification and description of test conditions. May be up to 80 characters long including blanks.

\section{Card type 4-controls for thinnings:}

ICUT - Control variable to determine the number of noncommercial thinnings that will be executed. A value of zero (0) causes all noncommercial thinnings to be bypassed. A value of one (1) allows only the initial thinning in the stand or a story to be noncommercial. Subsequent noncommercial thinnings will be bypassed. A value of two (2) allows all scheduled thinnings to be noncommercial. The values of COMCU and COMBF (card type 2) specify the minimum commercial limits.

DMLEV - Dwarf mistletoe rating above which thinnings will not be performed. Experience in ponderosa pine stands indicates that thinnings cannot materially reduce effects of the infestation or improve stand growth when DMR exceeds 3.0 (Myers and others 1976). Regeneration cuts will be performed when they are scheduled even if DMR exceeds DMLEV.

DELAY(1) - Number of years between initial age in yield table and first cut in the overstory. The value of DELAY(1) must be a multiple of the value of RINT (card type 1). DELAY(1) will have a value of zero if a cutting is desired at the initial age of the overstory in the yield table (AGEO(1), card type 5). An overmature overstory may be held past the normal final removal age, largest REGN (card type 6), by specifying a value of DELAY(1) equal to the difference between the desired removal age and the value of AGEO(1).

IOPT(1) - Control to specify whether the initial thinning in an infested overstory will be from above or below. Thinning from above emphasizes, but is not restricted to, removal of the larger trees. Such cutting is usual practice in infested stands because the larger trees usually support the greater amounts of dwarf mistletoe. IOPT(1) is assigned a value of zero $(0)$ if initial thinning is to be from above, and a value of one (1) if the initial thinning is to be from below. If the initial cut in the overstory is a regeneration cut, the cutting will be from below regardless of the value of IOPT(1).

THIN(1) - Growing stock level for initial thinning in the overstory. Values for THIN(1) will frequently be 80 to 100 , but may range from 40 to 160 . When thinning from above with THIN(1) assigned a value greater than 60.0, SWYLD2 reduces the value of THIN(1) to simulate additional removals for control purposes. The amount of reduction is based on the initial DMR and is given by the formula DMR/3.0 $\times(\mathrm{THIN}-60.0)$. If the initial DMR is greater than 3.0, then SWYLD2 assigns THIN(1) a value of 60.0 unless a lower input value is specified. 
DSTY(1) - Growing stock level for intermediate cuts after the first in the overstory. Value for DSTY(1) may be the same as the value for THIN(1). Values for DSTY(1) will also frequently be 80 to 100 , but may range from 40 to 160 .

JCYCL(1) - Interval in years between intermediate cuts in the overstory. The value of JCYCL(1) must be a nonzero multiple of the value of RINT (card type 1).

DELAY (2) - Number of years between initial age in yield table and first cut in the understory. With the exception of holding an overmature overstory, the discussion of DELAY(1) also applies to DELAY(2).

IOPT(2) - Control to specify whether the initial thinning in an infested understory will be from above or below. The discussion of IOPT(1) also applies to IOPT(2).

THIN(2) - Growing stock level for initial thinning in the understory. The discussion of THIN(1) also applies to THIN(2).

$\operatorname{DSTY}(2)-$ Growing stock level for intermediate cuts after the first in the understory. The discussion of DSTY(1) also applies to DSTY(2).

JCYCL(2) - Interval in years between intermediate cuts in the understory. The discussion of JCYCL(1) also applies to JCYCL(2).

\section{Card type 5-stand conditions:}

STND - Identification number of the stand.

SITE - Site index of the stand based on mean height of dominant and codominant trees in the overstory at total base age 100 years. Tables and graphs published by Meyer (1938) are appropriate. The value of SITE must be a reliable indicator of relative productivity. Trees in dense stands or with any disease or deformity that may reduce height growth do not furnish reliable information. In such cases, site index can be obtained from suitable nearby stands or from soil variables.

AGEO(1) - Mean total age in years of live overstory dominant and codominant trees at the first entry in the yield table.

$\mathrm{DBHO}(1)$ - Mean diameter breast height of all live overstory trees at age AGEO(1), regardless of crown class or species. The value of $\mathrm{DBHO}(1)$ should be determined to the nearest 0.1 inch. Average d.b.h. is the diameter of the tree of average basal area.

$\mathrm{HTSO}(1)$ - Mean height in feet of live overstory dominant and codominant trees at age AGEO(1). The value of HTSO(1) may be left blank when examining hypothetical stands with a density below growing stock level 160. For actual stands, the value of HTSO(1) should be determined from field measurements to account for the past effects of stand density and disease on height growth.

$\mathrm{DENO}(1)$ - Number of all live overstory trees per acre at age AGEO(1), regardless of crown class or species. Only trees over 4.5 feet tall should be counted.

DMR(1) - Average dwarf mistletoe rating of all live overstory trees at age AGEO(1).

PINF(1) - Percentage of the live overstory trees infected with dwarf mistletoe at age AGEO(1).

START(1) - Age of the overstory trees in years when the dwarf mistletoe infection began or is expected to begin in the overstory at various points throughout the stand. For an uninfested overstory, the value of START(1) must be greater than the largest REGN (card type 6).

$\mathrm{AGEO}(2)$ - Mean total age in years of live potential dominant and codominant trees in the understory at the first entry in the yield table.

$\mathrm{DBHO}(2)$ - Mean d.b.h. of all live understory trees at age AGEO(2), regardless of crown class or species. The discussion of $\mathrm{DBHO}(1)$ also applies to $\mathrm{DBHO}(2)$.

HTSO(2) - Mean height in feet of live potential dominant and codominant trees in the understory at age $\mathrm{AGEO}(2)$. The discussion of $\mathrm{HTSO}(1)$ also applies to $\mathrm{HTSO}(2)$.

$\mathrm{DENO}(2)$ - Number of all live understory trees, over 4.5 feet tall, per acre at age AGEO(2).

$\operatorname{DMR}(2)$ - Average dwarf mistletoe rating of all live understory trees at age AGEO(2).

PINF(2) - Percentage of the live understory trees infected with dwarf mistletoe at age AGEO(2).

START(2) - Age of the understory trees in years when the dwarf mistletoe infection began or is expected to begin in the understory at various points throughout the stand. The discussion of START(1) also applies to START(2). 
Card type 6-controls for regeneration cuts:

REGN(1) - Stand age in years when the first regeneration cut will occur. Must never be zero or blank. The value of REGN(1) is the age for clearcutting if the remainder of card type 6 is left blank. The value of REGN(1) must be equal to the values of AGEO for each story (card type 5) plus multiples of the value of RINT (card type 1). Therefore, it may be necessary to round off the values of AGEO(1) and AGEO(2) to the nearest ten years if the value of REGN(1) is a multiple of ten.

VLLV(1) - Percentage, as a decimal, of growing stock level for previous intermediate cuts, $\operatorname{DSTY}(1)$ and DSTY(2) (card type 4), to be retained at age REGN(1). Leave this and the next three variables blank if a clearcut system is being used.

REGN(2) - Stand age in years when the second regeneration cut, if any, will occur. This is the age when the final cut of a two-cut shelterwood or the second cut of a three-cut shelterwood will occur. The value of REGN(2) must be equal to the value of REGN(1) plus a nonzero multiple of the value of RINT (card type 1).

VLLV(2) - Percentage, as a decimal, of growing stock level retained after the first regeneration cut to be retained at age REGN(2). Leave this and the next variable blank if a twocut shelterwood system is being used.

REGN(3) - Stand age in years when the third regeneration cut, if any, will occur. This is the age when the final cut of a three-cut shelterwood will occur.

\section{Literature Cited}

Hawksworth, Frank G.

1961. Dwarfmistletoe of ponderosa pine in the Southwest. U.S. Dep. Agric., Tech. Bull. 1246, 112 p.

Hawksworth, Frank G., and Clifford A. Myers.

1973. Procedures for using yield simulation programs for dwarf mistletoe-infested lodgepole and ponderosa pine stands. USDA For. Serv. Res. Note RM-237, 4 p. Rocky Mt. For. and Range Exp. Stn., Fort Collins, Colo.

Meyer, Walter $\mathrm{H}$.

1938. Yield of even-aged stands of ponderosa pine. U.S. Dep. Agric. Tech. Bull. 630, 59 p.

Myers, Clifford A.

1971. Field and computer procedures for managed-stand yield tables. USDA For. Serv. Res. Pap. RM-79, 24 p. Rocky Mt. For. and Range Exp. Stn., Fort Collins, Colo.
Myers, Clifford A., Frank G. Hawksworth, and Paul C. Lightle.

1972. Simulating yields of southwestern ponderosa pine stands, including effects of dwarf mistletoe. USDA For. Serv. Res. Pap. RM-87, 16 p. Rocky Mt. For. and Range Exp. Stn., Fort Collins, Colo.

Myers, Clifford A., Carleton B. Edminster, and

Frank G. Hawksworth.

1976. SWYLD2: Yield tables for even-aged and two-storied stands of southwestern ponderosa pine, including effects of dwarf mistletoe. USDA For. Serv. Res. Pap. RM-163, 25 p. Rocky Mt. For. and Range Exp. Stn., Fort Collins, Colo.

Walters, James W.

1975. Evaluation of a dwarf mistletoe survey procedure. USDA For. Serv., For. Insect and Dis. Manage. Rep. R-3, 75-23, 7 p. Southwest. Reg., Albuquerque, N.M. 


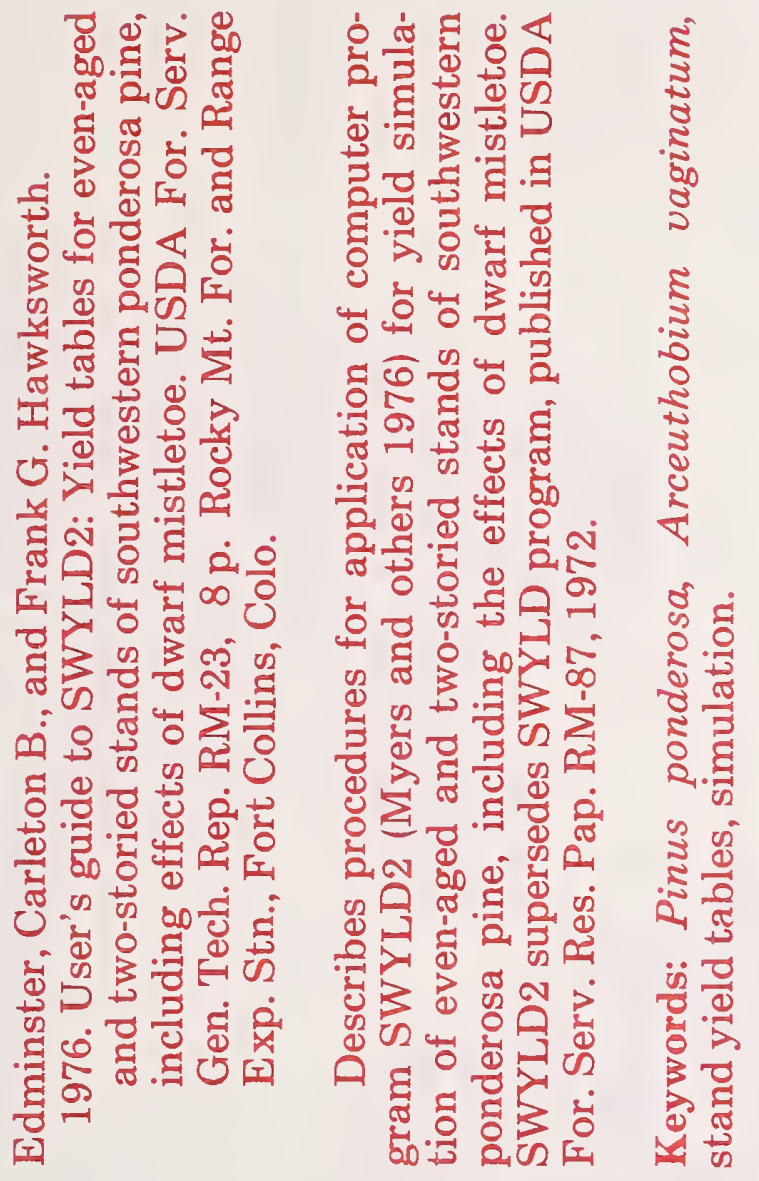

उ.

कृष

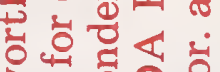

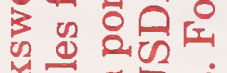

순음

雨

I 등

ن

ํㅕㄹ

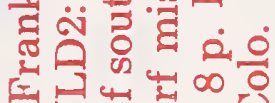

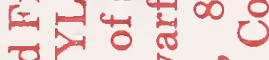

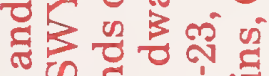

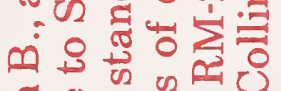

두웡 웡

흘

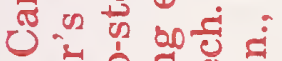

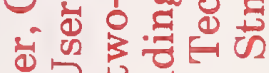



.

हृ 으

도
율

बै है

글뎔

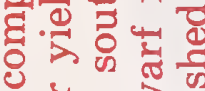

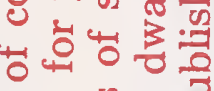

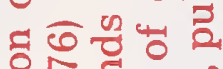

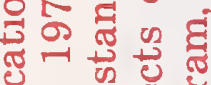

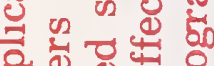

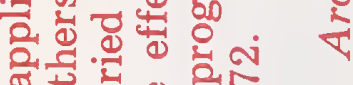

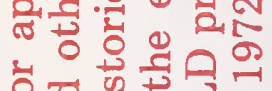

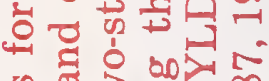

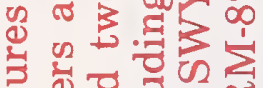

总记实的

造宁氜

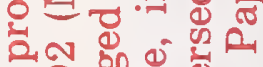

คิ

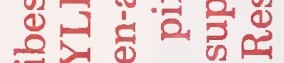

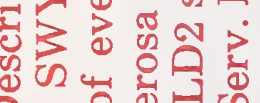

岁昰品

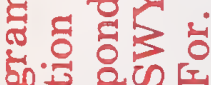

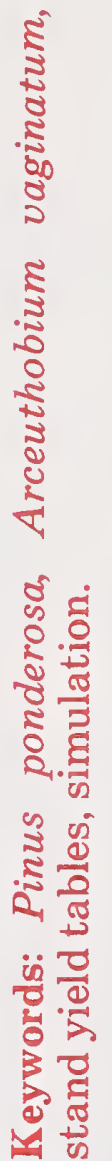

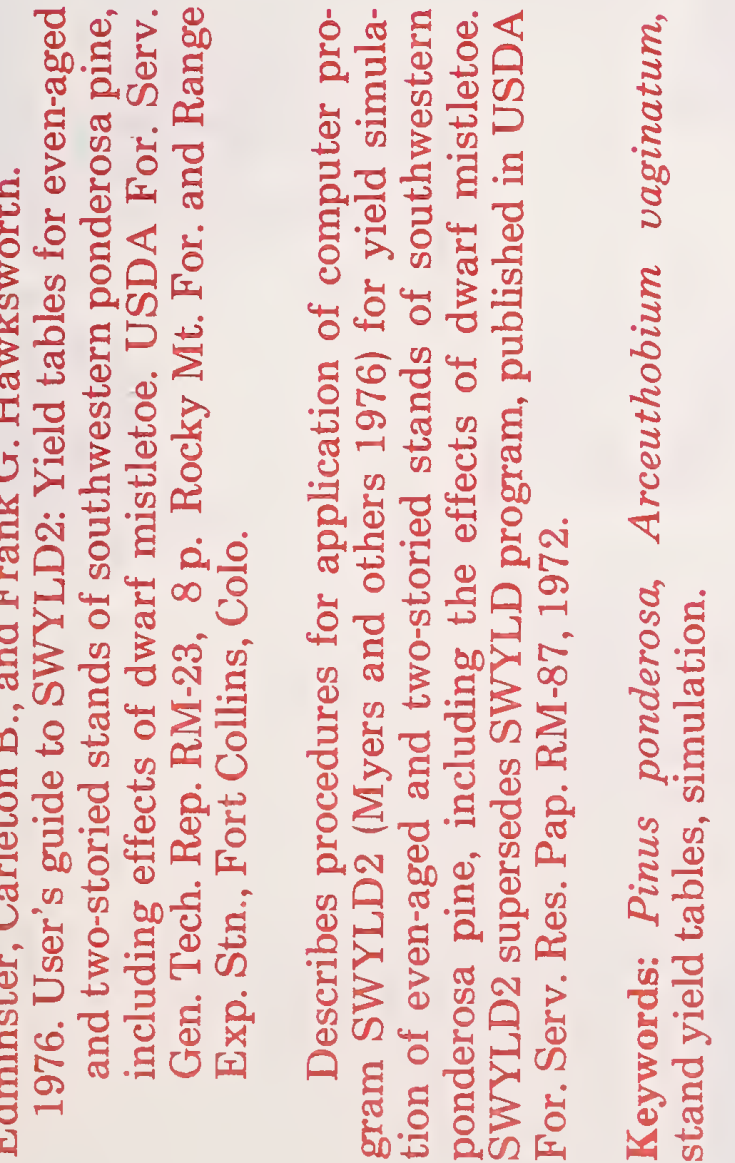

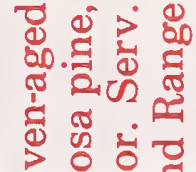

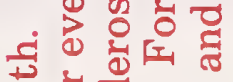

유윯

客造红

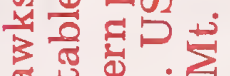

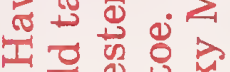

ऽ닐

서

ฮี

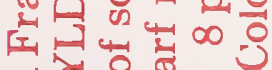

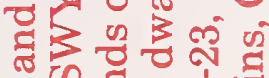

๑ْ

ธี ชิ ठ월

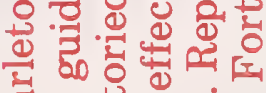

ठำ की

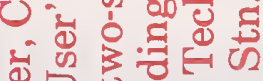

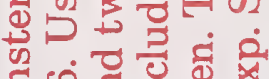

. 릉

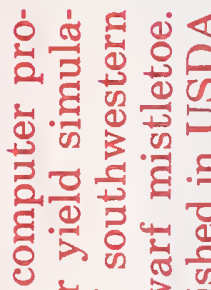

훙ㅎํ응

ㄷำ क्षै

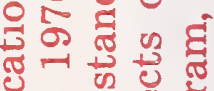

क क

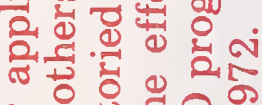

बे

여ำ

कू

일

屯ू.

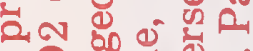

क

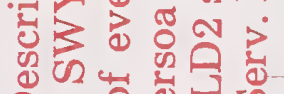

घ ฮี

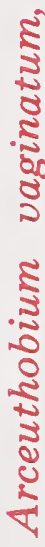

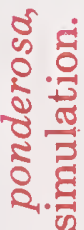

जิ की

म

ï융

ปั่

वृ 


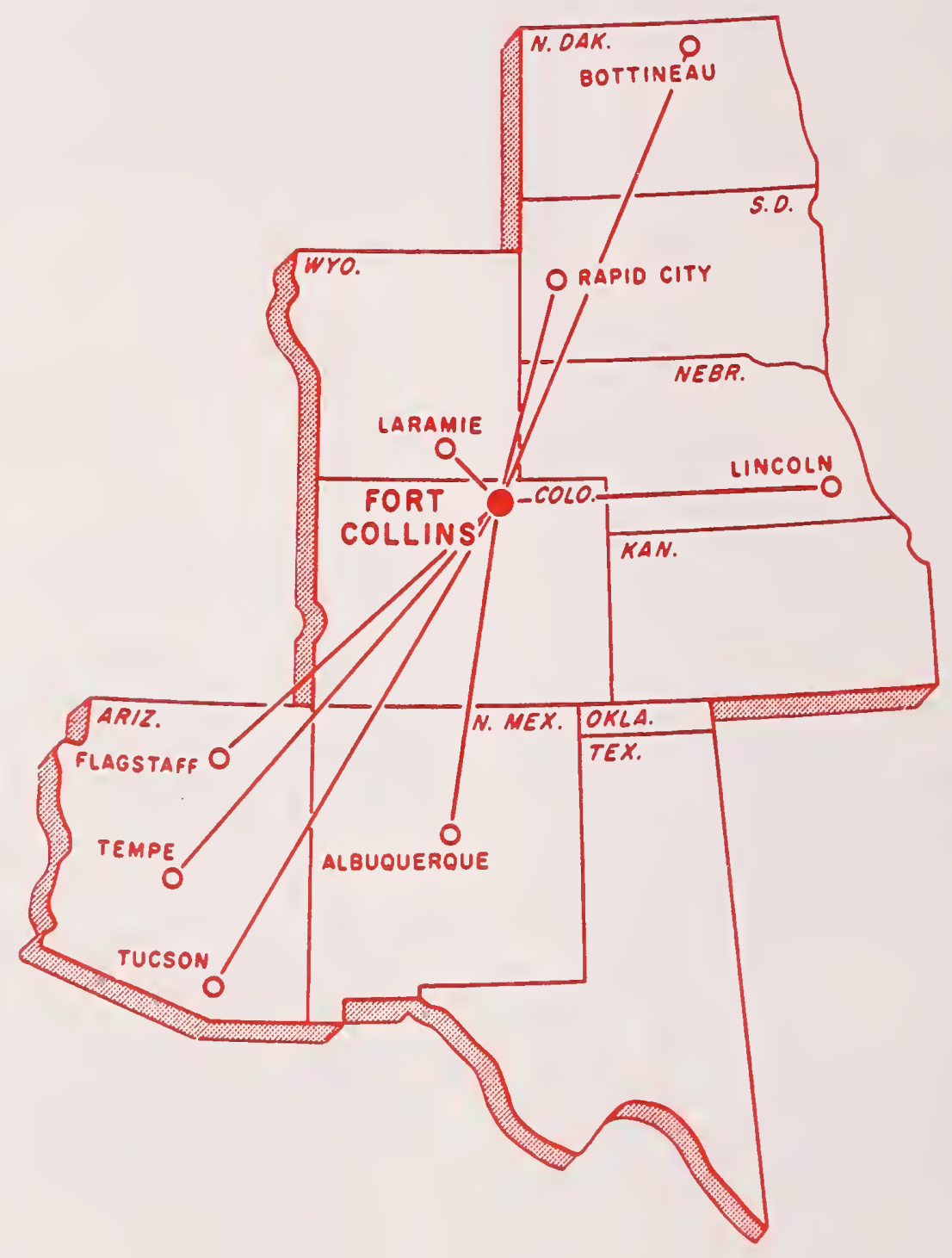

